\title{
Room-Mates Conflicts in Nigerian Universities: Causes and Management Strategies
}

\author{
Ebele Joyce Egwunyenga \\ Department of Educational Administration and Policy Studies, \\ Delta State University, Abraka, Nigeria \\ E-mail: jebele247@yahoo.com
}

KEYWORDS Room-Mates Conflict. Management Strategies. Federal Universities. State Universities. Private Universities. Nigeria

\begin{abstract}
It is axiomatic that the ability to manage conflict among roommates in universities in Nigeria with the right strategies will increase their capacity to relate to others and bring about positive change in cooperative attitude. This study was therefore designed to assess the causes and various strategies for managing roommate conflicts in Universities in Nigeria. A total of 1520 students made up of 724 from Federal owned Universities, 700 from State owned Universities, and 96 students from Private owned Universities were surveyed with a structured questionnaire. Data obtained were analyzed with mean score rating of 2.55. Results showed that smoking cigarettes in the room, use of roommate's property, gossiping a fellow roommate, noise-making, cooking inside the room, unacceptable prayers, members of different cults with differing interests, are some of the likely causes of conflict among roommates. Others are squatting friends, having an affair with a roommate's lovers, refusal to clean the room, competition in the use of electrical appliances, and refusal to settle common bills. On management strategies, encouraging communication among conflicting roommates, bringing together roommates to solve problems, using diplomacy to suppress conflicts, could ensure healthy roommate relationship. It was also observed that roommate conflicts are similar in Federal, State and Private owned Universities. It was recommended that special training could be organized for roommates in Nigeria Universities.
\end{abstract}

\section{INTRODUCTION}

Most universities in Nigeria offer full time and part-time diploma, certificate and degree programmes resulting in population explosion that they find difficult to effectively manage (Offiong 2002). As a result of expansion in student population, Vincent (2004) asserted that the activities in universities' environment are no longer clear and comprehensive as there is not enough money to finance them and provide equipment especially for teaching and learning, enough classroom, offices for staff to enable them carry out their responsibilities, provide enough hostels for students and adequate and qualified staff for teaching and research.

The students need comfortable accommodation in the universities for them to study hard and pass their examinations (Osagie 1993). The original idea of hostel accommodation was to provide a more conducive academic atmosphere for students. As a result, the first generation Universities built beautiful hostels, befitting the image of under-graduate and post-graduate students. Students' population then was within control. In some of the hostels, two or a maximum of three students occupied a room (Guardian
2004). Abubakar (2007) noted that students are supposed to be accommodated one per room and where two or more students shared a room often lead to conflict among them.

The Nigerian University students presently live under horrible condition on campus. Their accommodation is believed to be so bad and insanitary, congested and over crowded impeding the capability to learn effectively. A room with two wardrobes, which used to be allocated to two students in the past, now accommodates six students. Yet in such arrangement, not more than $40 \%$ of the students get official accommodation (Otobo 2002). Okebukola (2004) opined that in some rooms in the Federal and State Universities, 15 students share space meant for five. In some Universities, 24 students stayed in one big room originally meant for 10 students. The number of occupants rose because students' frequently squat their friends or relations who would reciprocate such actions in a later year. Thus rooms are often choked up with wears, buys and beguiles, resulting in less space for chairs and desks, making the rooms inadequate for personal study.

Edukugho (2006) claims that $80 \%$ of University student population live outside the campuses with many students becoming victims 
of shylock landlords and hostile communities, and persistently in bloody confrontation with host indigenes. Ten students or more living in a room is bad enough even in private hostels. Edukugho observed that students' welfare was still a far cry as many of them lived in filthy congested hostels which denies the students their comfort and privacy. Idachaba (2007) opined that over bloated admission of students into Nigerian Universities results in acute shortage in students' accommodation, which makes them live in over crowded rooms. Shalter (1970) asserted that when such number of youths from different backgrounds lives in a room together, there is always violent clash of irreconcilable interest, loyalties, values and opinions.

Conflicts are a common occurrence among roommates in Nigerian Universities all over the world. Roommates clash directly due to fundamental differences among them. Most fresh students in Universities move into the hostels or rented accommodations and for the first time, live with roommates who are strangers. They need to adjust to each other's quirks, habits and schedules, without causing inconveniences. Chruden and Shermans (1994) opined that, students who experience conflicts feel tensed and uncomfortable, a condition that is commonly referred to as anxiety.

Adjusting to hostel life is easier when expectations are realistic. Many students come into the hostel believing that their roommates will be their friends for life, while the roommates on the other hand may see the room only as a place to sleep, since they already have a social network. This leads to hurts, confusion and tension (Hepatica 2001).

\section{Statement of Problem}

Nigerian University students live within and outsider the campuses with many students to a room. The behaviour they exhibit toward each other often results in a series of conflicts among them. Some students exhibit deviant social behaviour in the room, some squat their friends or relation without informing other roommates, some practice their religion to offend other roommates, some use the fact that they belong to intimidate other roommates and roommates who support different contestants in student union elections and principal officers' of the Univer-sities in crisis period sometimes end up with conflict in their rooms. Patch (2004) noted that some roommates never contribute to bills, steal and use other roommate properties without permission and sell drugs in the room. Windmueller (2004) observed that some roommates' of the same sex have loud sexual relations, which may be against the religion and values of other roommates.

This paper therefore examined the major causes and management strategies of roommate conflicts in Nigerian Universities.

The following research questions were raised to guide the study.

1. What are the likely causes of roommate conflicts in universities in Nigeria?

2. Are the causes of roommate conflict similar in all categories of universities?

3. What management strategies can be adopted to address the situation?

\section{METHODS}

The population of this study was made up of students in 18 randomly selected Universities in Nigeria from the 89 Federal, State and Private Universities in the 2006/2007 academic session. The population of the students in the 18 universities was 314,884 made up of 150,025 students in federal owned universities, 144,936 students in state owned Universities and 19,923 from privately owned universities. From this population, the researcher sampled 1520 students or $0.483 \%$ (i.e. 724 students from Federal owned Universities, 700 students from State owned Universities and 96 students from privately owned Universities) with the simple random sampling technique.

The instrument used for data collection was the questionnaire. It was made up of 23 items each of which had the four point Likert rating scale of Strongly Agree (4 points) Agree (3 points), Disagree, (2 points) and Strongly Disagree (1 point). 1,520 copies of the questionnaire were distributed to the respondents. Data collected were analyzed using an internal scale of 0.05 and mean of 2.51 i.e. $\{0.05+2.5)$. The cut off point was fixed at 2.55. Therefore any item that received a mean score rating of 2.55 and above was regarded as agreed (positive), while any mean below 2.55 was regarded as disagreed (negative).

\section{RESULTS}

The likely causes of roommate conflict in 
Table 1: Mean scores of likely causes of roommate conflicts in universities in Nigeria.

\begin{tabular}{|c|c|c|c|c|c|c|c|}
\hline \multirow{3}{*}{$\begin{array}{l}\text { S. } \\
\text { No. }\end{array}$} & \multirow[t]{3}{*}{ Items } & \multicolumn{5}{|c|}{ Responses } & \multirow[t]{3}{*}{ Remarks } \\
\hline & & $S$ & $A$ & $A$ & $S D$ & & \\
\hline & & A4 & 3 & 2 & 1 & $X$ & \\
\hline 1. & Smoking inside the room. & 711 & 417 & 236 & 156 & 3.4 & Agree \\
\hline \multirow[t]{2}{*}{2.} & Making use of roommates' & & & & & & \\
\hline & properties without permission. & 531 & 479 & 301 & 209 & 3.1 & Agree \\
\hline 3. & Gossiping a fellow roommate. & 601 & 499 & 215 & 205 & 3.5 & Agree \\
\hline 4. & Noise making in the room. & 791 & 581 & 103 & 45 & 3.7 & Agree \\
\hline 5. & Cooking inside the room. & 639 & 597 & 217 & 67 & 3.3 & Agree \\
\hline \multirow[t]{2}{*}{6.} & Unacceptable prayer groups activities & & & & & & \\
\hline & by some members inside the room. & 621 & 687 & 192 & 20 & 3.2 & Agree \\
\hline \multirow[t]{2}{*}{7.} & Different cult members in a room & & & & & & \\
\hline & with different interests. & 901 & 431 & 127 & 61 & 3.8 & Agree \\
\hline 8. & $\begin{array}{l}\text { Roommates squatting too many friends } \\
\text { against what other members can tolerate. }\end{array}$ & 914 & 501 & 97 & 8 & 3.9 & Agree \\
\hline 9 . & Having an affair with a roommate's lover. & 639 & 597 & 217 & 67 & 3.3 & Agree \\
\hline 10 & Refusal to clean the room by some roommates. & 609 & 697 & 201 & 13 & 3.2 & Agree \\
\hline \multirow[t]{2}{*}{11} & Competition in the use of electrical & & & & & & \\
\hline & appliances before lecture time. & 519 & 695 & 217 & 89 & 3.1 & Agree \\
\hline 12 & Refusal of some roommates to settle bills. & 681 & 569 & 255 & 15 & 3.4 & Agree \\
\hline
\end{tabular}

Universities in Nigeria are presented in table 1.

Table 1 shows the response of students on the likely causes of roommates' conflict in Universities in Nigeria. The scores show that the respondents agreed in all the items as their mean scores were above the criterion level of acceptance of 2.55 .

This implies that all 12 factors mentioned above are accepted as the likely causes of roommates' conflicts in universities in Nigeria.

The results of similarity of causes of roommate's conflict in all 3 categories of universities are presented in table 2 .

Table 2 reveals that the cause of roommate conflicts are similar in all types of Universities in Nigeria but more so in federal and state owned than privately owned Universities. The responses also show that in spite of the fact that roommates conflicts in private Universities are similar to federal and state Universities in many areas, some causes such as. unacceptable prayer groups' activities by some members inside the room (2.43), different cult members in a room with different interest (1.11), some roommates squatting too many friends against what other members can tolerate (1.01), refusal of some roommates to settle bills (1.22) are not so common causes of roommate conflicts in private Universities in Nigeria.

The management strategies to address these conflicts are presented in table 3 .

Table 3 shows the mean rating of the responses of students on management strategies that can be adopted to address roommates' conflicts in Universities in Nigeria. The table

Table 2: Mean scores of the similarity or causes of roommate conflict in Federal, State and Private Universities.

\begin{tabular}{|c|c|c|c|c|}
\hline $\begin{array}{l}\text { S. } \\
\text { No }\end{array}$ & Items & Federal & State & Private \\
\hline 1. & Smoking insider the hostel room. & 3.71 & 3.83 & 2.97 \\
\hline 2. & Making use of roommate properties without permission. & 3.81 & 3.73 & 2.59 \\
\hline 3. & Gossiping a fellow roommate. & 3.37 & 3.12 & 2.51 \\
\hline 4. & Noise making in the room. & 3.03 & 3.61 & 2.49 \\
\hline 5. & Cooking inside the room. & 3.31 & 3.89 & 2.67 \\
\hline 6. & $\begin{array}{l}\text { Unacceptable prayer groups activities by some members' } \\
\text { insider the room. }\end{array}$ & 2.81 & 2.97 & 2.43 \\
\hline 7. & Different cult members in a room with different interest. & 3.02 & 3.57 & 1.11 \\
\hline 8. & $\begin{array}{l}\text { Roommates squatting too many friends against what other } \\
\text { members can tolerate. }\end{array}$ & 2.81 & 3.23 & 1.01 \\
\hline 9. & Taking roommate lover. & 2.93 & 3.01 & 2.74 \\
\hline 10 & Refusal to sweep the room by some roommates. & 3.59 & 3.62 & 3.84 \\
\hline 11 & Who will use electrical appliances first before lecture time? & 2.89 & 3.29 & 2.53 \\
\hline 12 & Refusal of some roommates to settle bills. & 2.97 & 3.11 & 1.22 \\
\hline
\end{tabular}


Table 3: Mean rating of management strategies that can be adopted to address roommates' conflicts (N = 1520)

\begin{tabular}{|c|c|c|c|c|c|c|c|}
\hline \multirow{3}{*}{$\begin{array}{l}\text { S. } \\
\text { No. }\end{array}$} & \multirow[t]{3}{*}{ Items } & \multicolumn{5}{|c|}{ Responses } & \multirow[t]{3}{*}{ Remarks } \\
\hline & & $S$ & $A$ & $A$ & $S D$ & & \\
\hline & & A4 & 3 & 2 & 1 & $X$ & \\
\hline \multirow{3}{*}{$\begin{array}{l}1 . \\
2 .\end{array}$} & Using rules and regulations to resolve the conflict. & 27 & 51 & 457 & 895 & 1.87 & Disagree \\
\hline & Encouraging some communication among & & & & & & \\
\hline & conflicting roommates. & 601 & 513 & 307 & 99 & 3.1 & Agree \\
\hline \multirow{2}{*}{$\begin{array}{l}3 . \\
4 .\end{array}$} & Using legitimate authority. & 38 & 153 & 510 & 719 & 1.67 & Disagree \\
\hline & the problem. & 400 & 515 & 203 & 402 & 2.7 & Agree \\
\hline \multirow{3}{*}{$\begin{array}{l}5 . \\
6 . \\
7 .\end{array}$} & Confrontation of the room-mates. & 152 & 217 & 385 & 766 & 1.87 & Disagree \\
\hline & Negotiation with the room-mates. & 201 & 311 & 417 & 591 & 1.84 & Disagree \\
\hline & $\begin{array}{l}\text { Bringing a third party outside the room to meet } \\
\text { with conflicting roommates. }\end{array}$ & 72 & 144 & 513 & 821 & 1.61 & Disagree \\
\hline \multirow{3}{*}{$\begin{array}{l}8 . \\
9 .\end{array}$} & $\begin{array}{l}\text { Rotating roommates to other hostel room on a } \\
\text { temporary basis. }\end{array}$ & 43 & 81 & 677 & 719 & 1.47 & Disagree \\
\hline & Organizing special training on developing & & & & & & \\
\hline & co-operative attitude among roommates. & 519 & 615 & 207 & 179 & 3.5 & Agree \\
\hline \multirow{2}{*}{$\begin{array}{l}10 . \\
11 .\end{array}$} & Using democratic means (majority rule). & 54 & 136 & 601 & 729 & 1.62 & Disagree \\
\hline & Using diplomacy to suppress conflicts. & 732 & 591 & 129 & 68 & 3.71 & Agree \\
\hline
\end{tabular}

reveals that the mean scores of respondents for three items of encouraging some communication among conflicting roommates (3.1), organizing special training on developing co-operative attitude among roommates (3.5) and using diplomacy to suppress conflicts (3.71) are above the criterion level of acceptance of 2.55. This implies that students do not encourage rules, regulations, democratic means rotation, confrontation and using third parties in solving roommates' conflict.

\section{DISCUSSION}

The findings of this study reveal that the respondents agreed that among many other factors that cause roommate conflicts are smoking inside the hostel room, making use of roommate properties without permission, gossiping a fellow roommates, noise making in the room, cooking inside the room, and unacceptable prayer groups activities by some members inside the room. Other factors identified are different cult members cohabiting in a room with different interests some bona fide roommates squatting too many friends against what other members can tolerate, having an affair with roommate's lover, refusal to clean the room by some roommates, competition in the use of electrical appliances before lecture time and refusal of some roommates to settle bills. This finding is in line with the views of Scott (2003) that conflict is a part of every human association
Peretomode (1995) further added that conflict results among people with different backgrounds based on their needs, goals, skills, talent, status, prejudice, aggressiveness, and perceptions. that conflict is inevitable, unavoidable, natural and normal part of the relationships.

This study also found out that roommate conflicts in Federal, State and Private Universities are similar but problems such as cult members in a room with different interests, some roommates squatting too many friend and refusal of some roommates to settle bills are not noticeable causes of roommate conflicts among students in private Universities in Nigeria.

On the issue of management strategies that can be adopted to address roommate conflicts in Universities in Nigeria, it was observed that encouraging communication among conflicting roommates, bringing together roommates to resolve a problem, organizing special training on developing cooperative attitude among roommates and using diplomacy to suppress conflict can be adopted to resolve roommate conflict. This finding agrees with the views of Residence Life Apartment Area Office (2005) that a big part of living with roommates is communication, which can be the saving grace in a successful roommate relationship. Daft (1995) observed that bringing together conflicting roommates in joint problem solving is an effective way to reduce room conflicts. Gillin (2004) also noted that diplomacy should be applied in resolving roommate differences. 


\section{CONCLUSION}

Conflict occurs among roommates in Universities in Nigeria due to negative behaviours exhibited by members in same room. The different management strategies suggested by respondents show that students appreciate the need for some techniques that can be designed and utilized to bring about positive change in co-operative attitude among roommates in universities in Nigeria. Again factors that cause roommate conflict in Universities are similar but some factors like differences in cult group membership, conflicts due to squatting too many friends by roommates, refusal to settle bills are not noticed among roommates in private Universities in Nigeria.

\section{RECOMMENDATIONS}

Arising from the above findings, the following recommendations are made. Implemental regulations to check negative behaviour are made to students in halls of residence. Proprietors of universities should build more official students hostels to reduce congestion and over-crowded rooms.

\section{REFERENCES}

Abubakar A 2007. Granting Permission to Private Universities Worthwhile? A paper at the Babcock University Second Eminent Persons Day in Illishan Ogun State 15th March, 2007, P. 2.

Beals AR, Siegel BJ 1966. Divisiveness and Social Conflicts: An Anthropological Approach. Stanford CA: Stanford Universities Press.

Chruden HJ, Sherman AW.1994. Managing Human Resources. Dallas: South-western Publishing Company.

Daft R 1995. Organizational Theory and Design. LosAngeles: West Publishing Company, Fourth Edition.

Edukugbo E 2006. Moving Universities System Forward: Challenges Involved. Vanguard Newspaper, Daily, January $26^{\text {th }}$, P. 17

Gillin CT. 2004. Conflict Resolution, Negotiation and Team Building. Reviewing an Impossible. Course at Work, 5: 1 .
Guardian Newspapers 2004. Private Sector Participation in University Hostels. Guardian Newspaper, Daily, December $13^{\text {th }}$, P. 16.

Hepatica S 2001. Dorm Life: Surviving the Roommate Crisis. From the August Issue of the Northern California Bohemian. Copyright at Metro Publishing Incorporated. Maintained by Boulevards New Media.

Idachaba F. 2007. in Vanguard Newspaper, Education Weekly, February 15, 2007, P. 40.

Marek J 1966. Conflict, a Battle of Strategies. In: J Lawrence (Ed.): Organizational Research and the Social Science. London: Tavistock.

Okebukola P 2004. Private Sectors will Participate in University Hostels. A government policy paper presented at $56^{\text {th }}$ Convocation Ceremony of the University of Ibadan., Ibadan

Osagie RO 1993. Dropout in the University of Benin. M.Ed. Dissertation, (Unpublished) Benin: Faculty of Education, University of Benin.

Otobo JO 2002. in Vanguard Newspaper, Education weekly, June $6^{\text {th }}, 2002$, P. 33.

Patch J 2004 Smart Tips for Dealing with Tough Roommates Situations. Education Foundation: http://www.ifoungmoney.com/lifestyles/campus Life/ 0307160. (Retrieved October 16, 2007)

Peretomode VF 1995. Conflict Management. Lagos: Obasoh and Ogbinaka Publishers Ltd.

Raimi D 2006. Challenges Confronting Federal University of Science and Technology Akure. Paper presented at the $18^{\text {th }}$ Graduation Ceremony of the Federal University of Science and Technology Akure, June $18^{\text {th }}, 2006$.

Residence Life Apartment Office 2005. Living and Getting Along with Roommates. Show letter? Msgld $=4350$ 51412128415434285091621590920909 ? 1 ?X $=5$ ?YY(Retrieved December 14, 2007)

Rose SC 1964. Saul Alinsky and His Critics. Journal of Christianity and Crisis, xxiv: 145.

Shalter LS 1970. Conflict over Conflict. In: FM Cox, JL Erlich, J Ruthman, JE Tropman (Eds.): Strategies of Community. A Book of Reading. Itasca: F.E: Reacock Publishers Incorporated.

Schmidt SM, Kochan TA 1972. Administrative Science Quarterly, 13: 359-370.

Scott J 2003. Famous Roommates: Real Life Issues. http://www. Students. Com/factors/roommates.html Retrieved December 12, 2007)

Vincent T 2004. How to Reverse Decay in Tertiary Institutions. Guardian Newspaper, Daily, February $26^{\text {th }}, 2004$

Windmueller J 2004. Conflict Management in Higher Education Report 5:1 September/show letter? Msgld=8713 $113823 \quad 1996,15240 \quad 1385356$ 3309015639 ? Idx $=3$ ? Y4/42005 (Retrieved December 12, 2007) 